\title{
form
}

\section{Manifestations of social resistance in craft processes}

\author{
Iku, Nasa and Sami indigenous craft
}

\begin{abstract}
This paper aims to analyze craft objects that could contain inherent meanings of social, cultural, ecological or political resistance. The creative processes of makers from the Iku and Nasa indigenous peoples of Colombia and the Sami people of Sweden have been studied. The paper encompasses a theoretical reflection on the communicative capacity of objects and their implicit meanings as well as of the basic concepts of resistance and craft paired with a brief description of the Iku, Nasa and Sami indigenous peoples. An analysis of the manifestations that could be considered as resistance in the studied artisanal processes is brought forward through 11 interviews with makers and the paper proposes a final reflection on how craft objects can have the capacity to communicate social, cultural, political and ecological resistance.
\end{abstract}

Keywords:

Craft, design, indigenous peoples, social resistance, sustainability.

\section{INTRODUCTION}

Many authors have studied the communicative character of objects and the close relation between everyday items and the preservation and transmission of a shared collective imaginary which characterizes a semiotic sphere ${ }^{1}$. According to Alfredo Tenoch Cid Jurado, professor and investigator of the Autonomous Metropolitan University of Mexico, all objects are bearers of cultural connotations and contain a communicative efficiency of social values depending on their nature (Jurado 2002,2). The objects can satisfy not only basic needs, but rather be configured as signs that communicate different values such as status, tradition, femineity, modernity, elegance, etc. An object can act as a narrative medium with the capacity to communicate the context and the necessary technical and cultural 
conditions for its production. According to Jurado, when a detailed analysis of an object is undertaken, it is fundamental to study the role of the physical and social surroundings as these elements constitute the specific cultural context that motivates its creation².

The relation between social resistance and textile making was probably addressed for the first time by Mahatma Gandhi. According to Mario López Martinez, investigator at the department of contemporary history at the University of Granada, Gandhi's ethical-political philosophy ("Satyagraha"), is based on social and economic conscience, direct action, civil disobedience and self-governance in the framework of the principle of non-violence ("Ahimsa") or "do no harm"3. The "Satyagraha" is accompanied by the principle of "swadeshi" which makes reference to development and local, social, political and economic welfare. The "swadeshi" revendicates self-sufficiency and economic autarchy through local artisanal practices. From a Gandhian perspective, self-sufficiency depicts a morally and ethically correct economy which is distant from the interests of the colonial market.

In this paper, Craft will be understood as a process, practice and as an object. Using the definition proposed by Fariello (2011), craft is understood as a work- and making- process that requires manual skills. Craft is also seen as an artistic and cultural practice that supposes a body of produced objects that play a specific role in contrast to another class of objects that are oriented towards the practice of consumption (Mazanti 2011). Finally, craft will also be understood as the making of usable artifacts in a specific material that serves as "medium" and that are individually handmade and produced with great virtuosity (Cardoso 2010).

\section{Objective and research question}

This research seeks to identify manifestations of social and cultural resistance in craft created by specific indigenous communities in Colombia and Sweden. The research question is: can craft created by indigenous communities be understood as a method of social and cultural resistance?

\section{The Iku, Nasa and Sami peoples}

According to the National Indigenous Organization of Colombia (ONIC for its Spanish acronym), there are 102 indigenous peoples distributed in the national territory, although only 87 of them are officially recognized by the Colombian state. The Iku are one of the recognized indigenous ethnic groups and is comprised by 14799 individuals. Indigenous peoples, such as the Iku, have historically been exposed to permanent violence against their territories, traditional culture and autonomy in Colombia.

Since the beginning of the 20th century, the Iku people has suffered the consequences of external interventions by colonizers, farmers and foreigners. A crucial incident that affected the Iku's struggle for self-governance consisted in the installment of a Capuchin mission sent out from Bogota in the Sierra Nevada in 1916 during that time Iku women were prohibited to conduct traditional activities, such as knitting. The existence of the Iku people has continued to be threatened by illegal armed groups, conflicts with the government over the use of their territories and the frequent clashes between their cultural practices and the cultural practices of the "modern western world". Notwithstanding the above, the Iku have been able to maintain alive their traditional weaving-activities as an expression of their material culture. The bag traditionally produced by lku women is commonly known in Colombia as the "mochila arhuaca". The name that the Iku give to the same bag in their language is "Tutu". The word "Arhuaca/Arhuaco" is the term used by the Spanish colonizers to describe the region inhabited by the Iku and its use is nowadays widespread and void of negative meaning. The term "mochila" is commonly used to describe this particular type of bag produced by Iku women ${ }^{4}$. In this paper, the author will use the pre-colonial term "Iku" to describe the people and the term "mochila Iku" to describe the object.

The Nasa people is comprised by 186178 persons and represents $13,4 \%$ of the indigenous population in Colombia. The ancestral territory of the Nasa people is situated in the valleys of the rivers Páez and la Plata to the south, and the rivers Yaguará and Páez to the east, with the largest concentration in the region of Tierradentro in the administrative areas of Huila and Cauca. Some of the members of the Nasa people reside in the Valle region and others have migrated to the Caquetá and Putumayo regions. Their language (Nasa Yuwe or Páez) is one of the most used indigenous languages in 
Colombia. (ONIC, 2020). The Nasa are predominantly farmers and their economy is characterized by small scale polyculture for self-consumption. Within the indigenous mentality, to be Nasa implies being a good farmer (ONIC, 2020).

They have applied different strategies over the years, such as social protests in order to recover their lands and defend the Mother Earth. In their world view, nature is the foremost material and spiritual foundation.

The armed conflict in Colombia has put at risk the collective and individual rights to life, territory, health, self-governing and survival of these indigenous peoples. (Vargas Reyes, B. \& Ariza Santamaria, R. 2019). In spite of the constant threats, the Nasa people are reproducing their cultural traditions, collective memory and their unique world views through everyday life.

The land of the Sami people, whose ancestral territories are known as Sápmi, extends over parts of Sweden, Norway and Russia. Between 20000 to 40000 persons identify as Samis in Sweden alone and their language has three different dialects in Sweden: Northern Sami, Lule Sami and Southern Sami. The Sami people shares a history of colonization and risks of cultural extinction with other indigenous peoples such as the Iku or the Nasa. Their language, religion and ancestral customs were suppressed when they entered into contact with the Nation States. The imposition of Christianity, attendance to church and religious education hindered the traditional ways of life and reindeer-herding.

Although the International Labor Organization's convention 169 was adopted 1991 and has been ratified by 23 countries to protect and safeguard the rights of indigenous peoples all over the world, Sweden, as opposed to Norway has not signed this convention. The fact that Sweden has yet to sign the convention, means that the Sami people still does not count with all the guarantees for the free exercise of their ancestral customs and the right to their lands continues to be one of the major conflicts between the Swedish state and the Sami people.

With a past marked by cultural oppression and threats against their language and culture, this people maintain its traditional craft - just as the Iku and the Nasa - as a fundamental component of their material culture. The Sami craft, known as Duodji, has been essential for the reproduction of their culture, whilst adopting new elements in a craft practice rich in symbology and meaning.

\section{Methodology and participants}

This paper pretends to create a space for conversation between craft practitioners and artists from different indigenous peoples who have shared their creative experiences, stories and craft knowledge. The study of the indigenous craft objects and processes was made with a qualitative-descriptive approach in the understanding that the unit of analysis is craft as a process and as an object. The cultural, social and political context in which the creative process took place has been taken into account, as well as the accounts and histories of the makers. The chosen methodological approach for this paper is based on ethnography.

In the cases of the Iku and Nasa peoples, the methods of information-gathering applied consisted in bibliographic- and virtual contents review, remote interviews and communication through virtual platforms such as Facebook, Gmail and whatsapp. A visit to the ancestral Iku territory planned to take place in June 2020 had to be suspended due to the COVID - 19 pandemic. The bibliographic review produced a large quantity of previous ethnographic investigations that were useful for this paper.

In the Iku- case, the accounts of the Iku activist Ati Quigua and the artisan and Iku- leader Seynari Torres were fundamental as a complement to the information that was acquired through the consulted literature.

In the Nasa case, litterature review and the review of virtual contents was also important. Additionally, a contact with the indigenous artisan women's association "Tangle up with identity" (Enredarte con identidad in Spanish) was established in order to gain access to four Nasa artisans that were interviewed: Rosa Elena Campo Aposta, Ofelia Escué Pavi, Fabiola Coicué y John Rocha.

In the Sami case, the information was collected from direct sources through fieldwork, reflexive diaries, direct observation, conversations and interviews with the makers of the artisanal objects. The field visits were made in October 2019 (Tärnaby) and February 2020 (Jokkmokk). The interviews with the Sami 
academic Gunvor Guttorm, the artist Britta Marakat-Labba and the artisans Doris Risfjell and Åke Risfjell were carried out during the winter market of Jokkmokk. The interview with the Sami artist Tomas Colbengtson took place in the installations of Konstfack art school in Stockholm, Sweden.

The participants were subjected to a semi-structured interview designed to respond to the following goals: I. The identification of intangible or non-material functions of the artisanal objects, II. The identification and analysis of materials, techniques, colors and patterns involved in the making of the craft objects. III. The mapping of the means of transference and survival of the artisanal knowledge. IV. The identification of social resistance in craft and its creative processes.

The interviews were processed manually, grouping convergences and divergences and applying the voyant.tool - software in order to identify key concepts and coincidences in the responses to the interview. The analysis gave at hand four common categories with manifestations of social resistance: i) Craft: sustainability, environment and technical processes; ii) craft, cultural resistance and the continuity of the world view and symbolism; iii) Craft: adaptive resistance, new meanings and functions; iv) the survival of knowledge and threats.

\section{MANIFESTATIONS OF SOCIAL RESISTANCE}

\section{Craft: sustainability, environment and technical processes}

The responses obtained during the interviews indicate that the relationship with nature has been an essential part of Sami craft practices. The world view is profoundly rooted in the idea of living off the land without leaving traces for the benefit of future generations. Nature is taken into account not only as a source of inspiration but also as a source of essential material in their craft processes.

The use of available resources and the close relation between Sami craft and local nature is visible in the traditional materials used in the process of production of the craft objects, especially so with the use of materials that originate from the reindeer and the moose. The leather, bones and antlers are materials constantly used to produce knifes and bags, among other objects (figure 1). According to the Sami world view, nature relinquished half of the reindeer in the world to them so that they could be domesticated and used for their survival. For the Samis, the domination of the art of reindeer herding signifies that the reindeers trust them and coexist in mutual benefit. Without the reindeer there would be no Samis. It is also indigenous custom to honor the slaughtered animal with prayers. To consume the meat also means to learn how to never let any part of the animal go to waste, as this is seen as an insult to the spirit of the animal. It is thus of utter importance to utilize all the different parts of the animal such as the leather, the wool, the bones and the antlers (Kraus 2014)

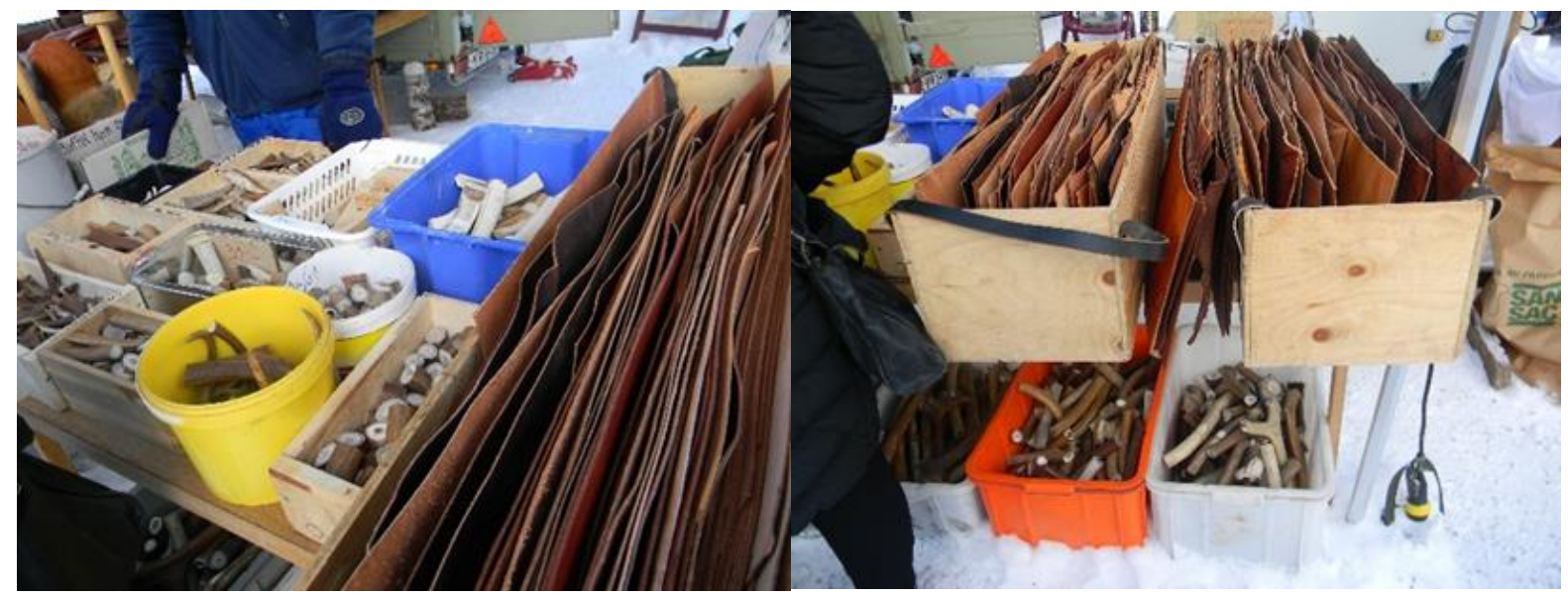

FIGURE 1. Materials offered in the 2020 Jokkmokk's market. Photo: Stefanía Castelblanco. 
For the artist Britta Marakatt - Labba, nature constitutes a source of inspiration. The colors of nature during the different seasons and Sami mythology are important elements of her creative process. "For me, nature, Sami history and Sami mythology are a source of inspiration, as well as recent world- and environmental events and the present social and political situation" (see figure 2). Marakatt - Labba considers that the Sami ways of production, the consideration and respect for nature are customs that should be promoted and replicated in these times of environmental crises. The artist is worried about sustainability and present governmental policies that put the Sami culture and landscape at risk.

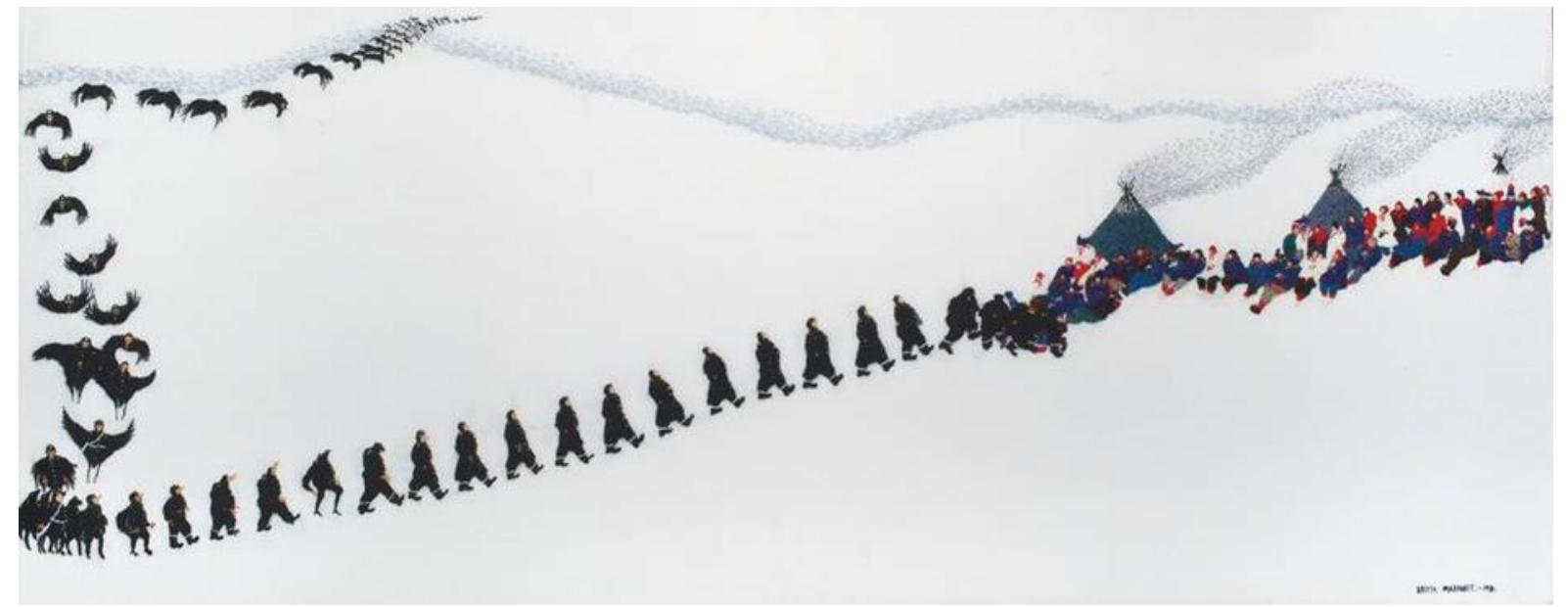

FIGURE 2. Embroidered tapestry. Britta Marakatt Labba. Kråkorna 1981.

For Gunvor Guttorm, professor of Duodji at the Sami University of applies sciences, the respect for nature and the concern for future generations is a central theme. Guttorm has written several articles on how the traditional knowledge of Sami art and craft - the Duodji - adapts to modern lifestyle. Sustainability is primordial in her activity as Duojár (artisan). "Nowadays, when I'm more and more conscious of sustainability, I believe it to be important that we produce objects that have a specific function in our daily life as we should be aware of the very short distance between the producer and the user". The reason for her to be involved in duodji was to create items with a utilitarian function and thus avoiding the production of unnecessary objects. This reflection is of great relevance when discussing the environmental impacts of mass production which is characteristic for contemporary design. With respect to the used materials she expresses that: "I like to work with antlers as the reindeer antler is a locally available natural material. I also like to work with other natural materials such as birchwood and bark because for me there is a connection between these natural materials and what nature in itself gives me as it is a part of my life".

According to her, sustainability is discussed in Sami schools and she affirms that the young students are more and more conscious of this concept. "I hear young people that really reflect on this connection with the material and where it is found. Therefore, bark is important for young people to work with as it is a very gratifying material that is found in the local environment, as well as antlers as these materials are sustainable. We of course also use many other materials that are not as sustainable".

At the Jokkmokk Winter market many Sami artisans offer traditional objects made from materials of vegetal origin, such as the birch bark which is used in artisanal objects such as drums, pots and wooden sculptures. (figure 3 ) 


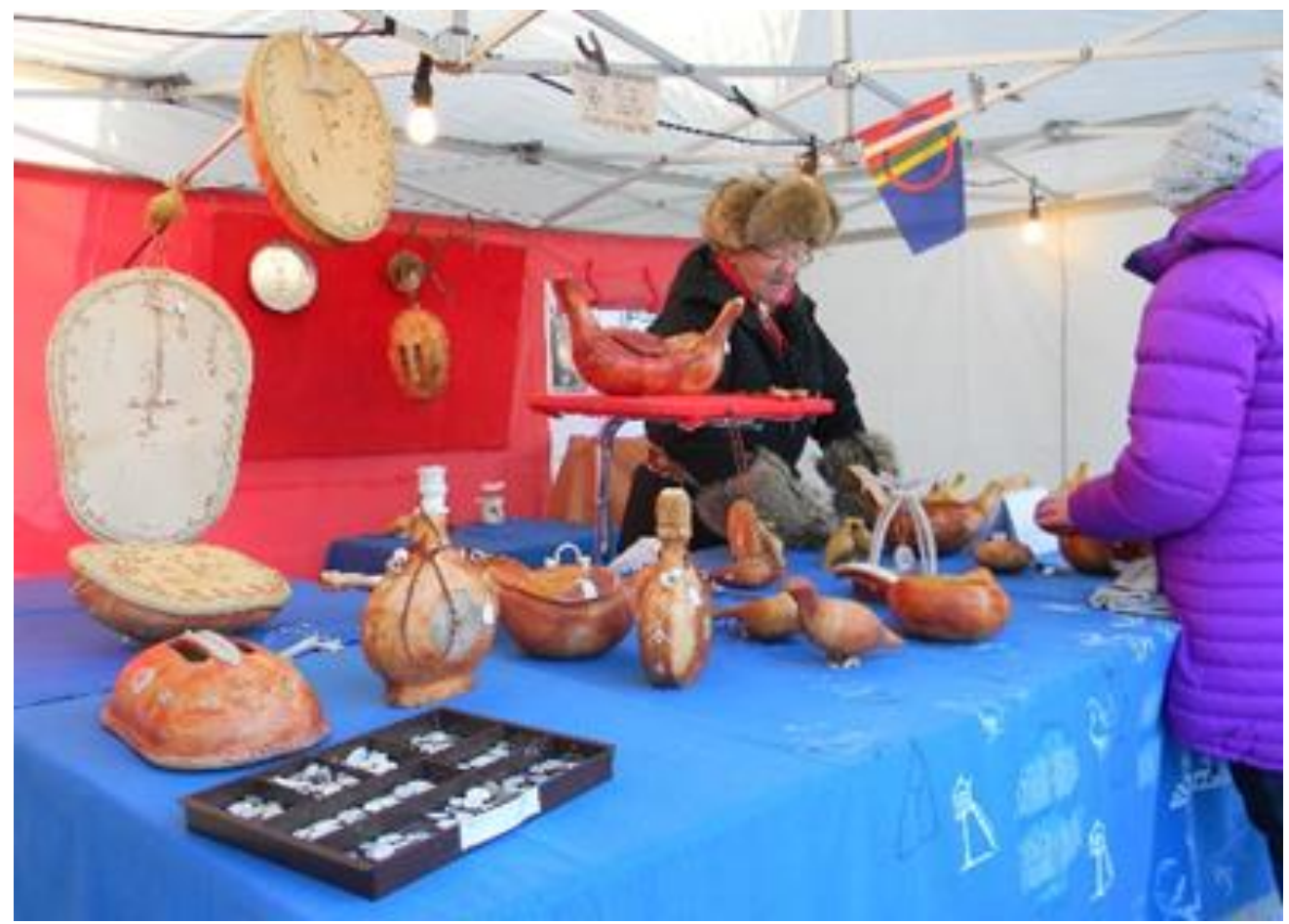

FIGURE 3. Artisan Tyko Lampa in Jokkmokks Winter Market 2020. Photo: Stefanía Castelblanco.

For the South Sami artist Doris Risfjell, the use of materials that preferably stem from local sources is the best way to conserve traditional Duodji. The artisanal bags made by Doris are made from reindeer leather and adorned with traditional tin thread (figure 4). "I use traditional materials. If I do a bag, I need reindeer leather. Sometimes, I can use some salmon skin as decoration but not cow leather or something that is not from reindeer (...) I also like to incorporate the four traditional colors of the south Sami region".

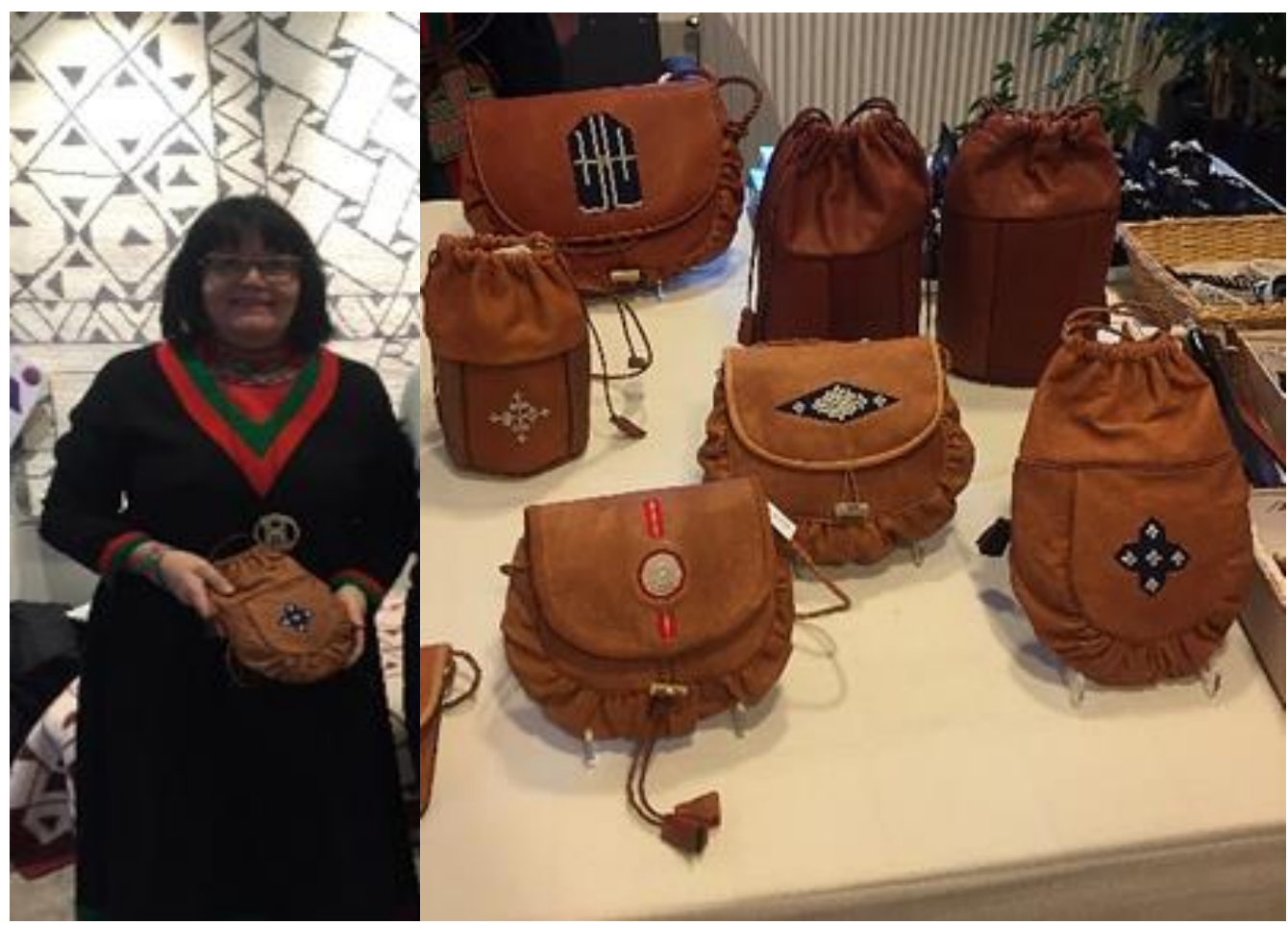

FIGURE 4. Artisan Doris Risfjell showing her pouches. Photo: Stefanía Castelblanco. 
For the Iku worldview, nature has played an essential role as a source of inspiration and materials for the creation of mochilas Iku. Previous studies of the bag's symbolism have identified 16 traditional knitted figures, each geometric shape referring to an element of nature ${ }^{5}$.

Traditional Iku bags are made from natural fibers locally sourced such as wool, cotton or fique ${ }^{6}$. After being properly prepared, they are wound on the spindle to finally start the process of knitting the with the needle. For the activist, Iku leader and Bogotá council member Ati Quigua, "it is not possible to grow without serving Mother Earth". The last term used by her is common among indigenous people in Colombia in reference to nature. Quigua explains that the fibers used for the mochilas traditionally come from natural materials of local origin and that the designs used have a meaning. The traditional designs and shapes of the mochila represent the Iku view of nature and that "the mochila is the place where the Iku/Arhuaco woman expresses her thoughts and reflections". (Figure 5).

According to her account, the traditional colors are natural and are extracted from endemic plants. The color yellow stems from the peel of a certain plant and the darker colors originate from roots and seeds that are manually processed for the coloring of the cotton. She arguments that locally produced cotton is preferred. Unfortunately, the introduction of transgenic cotton to Colombia has generated contamination of the local varieties of cotton that grows in the Sierra Nevada region.

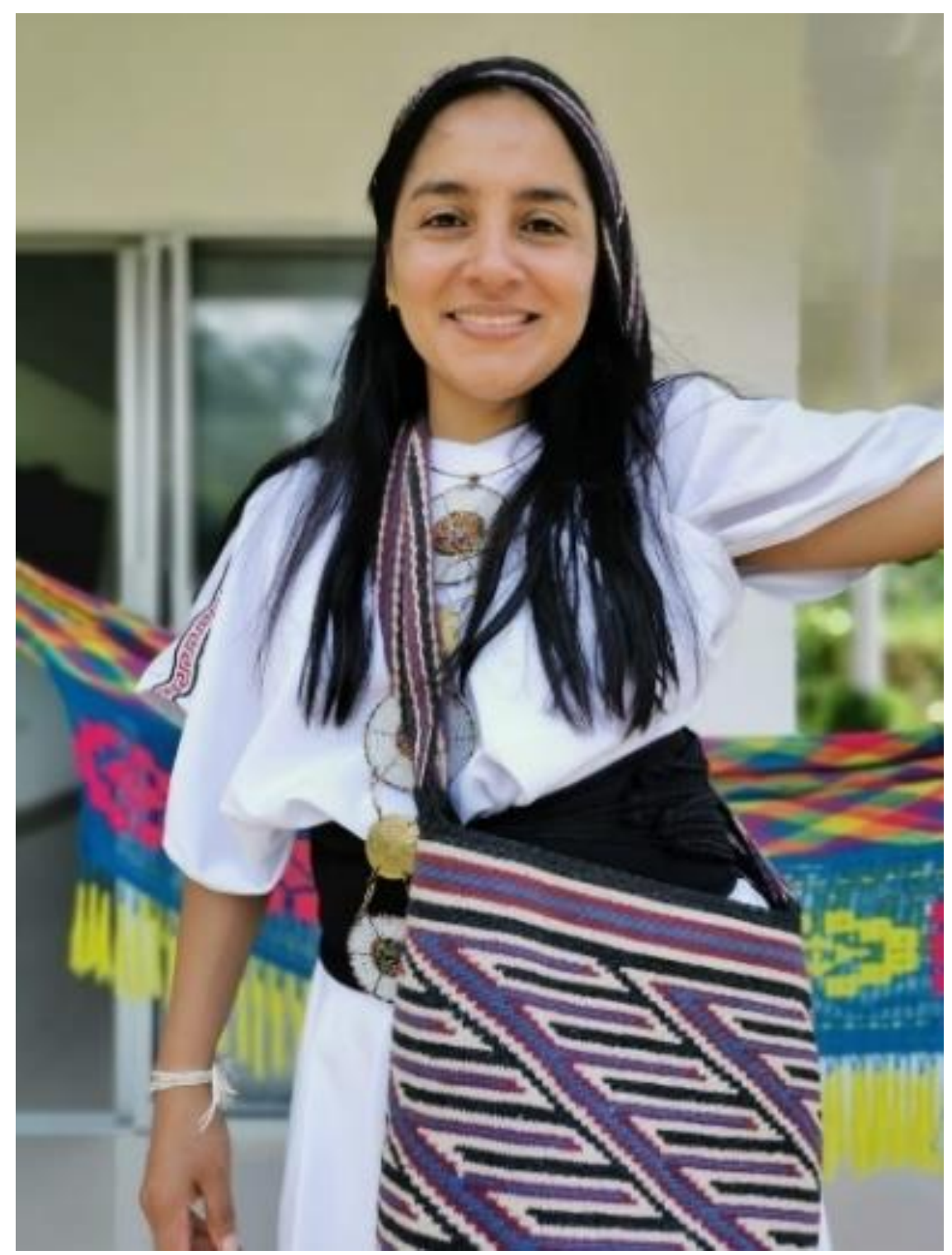

FIGURE 5. Iku Indigenous leader Ati Quigua. Photo: Ati Quigua. 
According to Iku leader and artisan Seynari, currently the fabrics of her culture are made with different materials, including synthetic and processed threads, natural fibers from the Maguey plant (figure 6) and processed threads from sheep wool. According to her, the most used colors when utilizing sheep wool are the neutral ones. These are earth-colors such as grey, black, white and brown. Notwithstanding the above, she explains that the colors are changing now due to the use of processed threads that come from external markets.

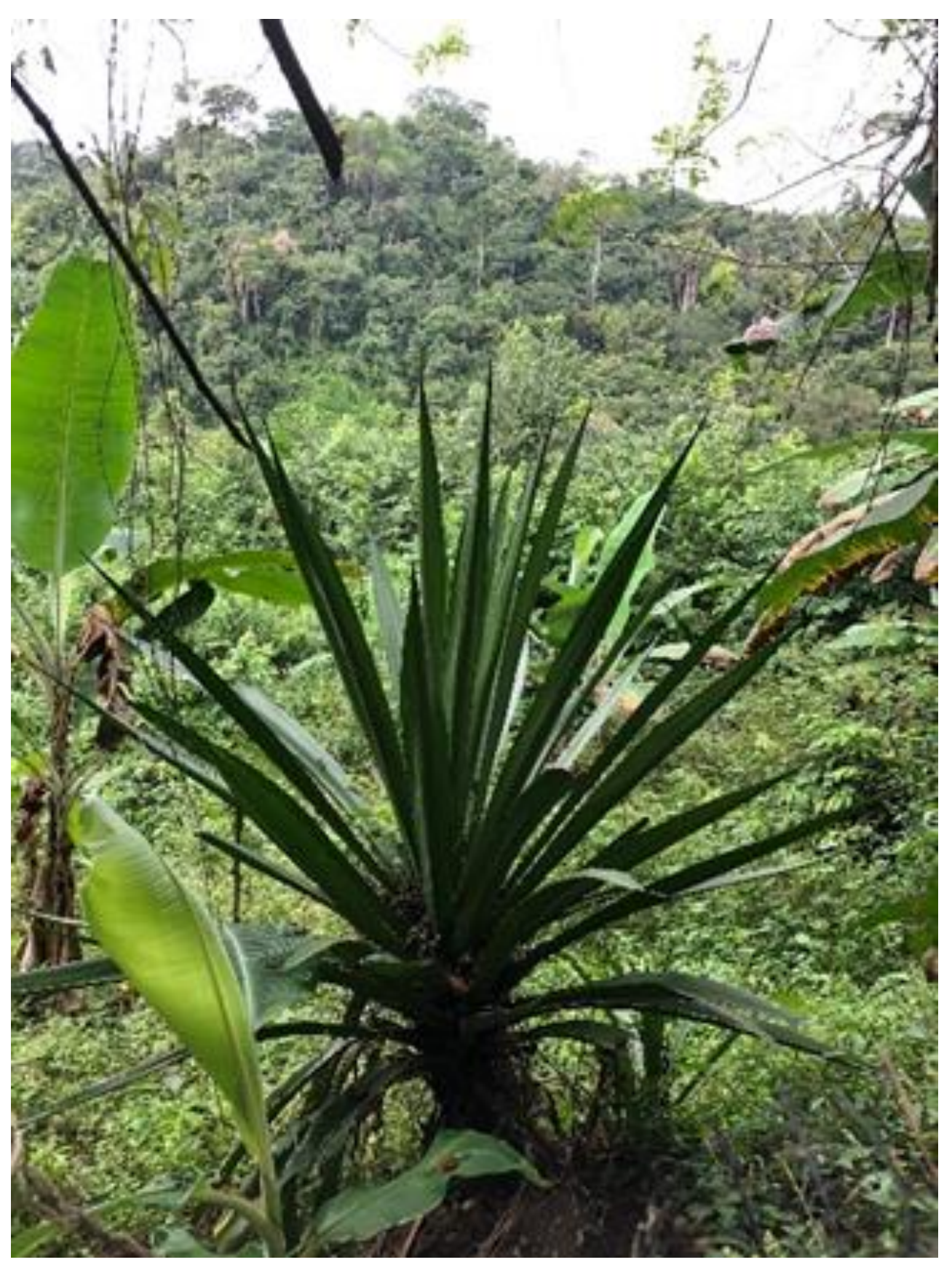

FIGURE 6. Maguey plant in the Sierra Nevada de Santa Marta. Photo: Stefanía Castelblanco.

The Nasa people seem to have a similar interpretation of nature. Coicue explains that the chumbe ${ }^{7}$ represents everything that nature gives. For Escué Pavi, everything needed for their craft is available in the nature that surrounds them, such as the cabuya plant. "We only have to ask the spirits for permission to cut it, scrape it and later on make threads from it" (Figure 7). 


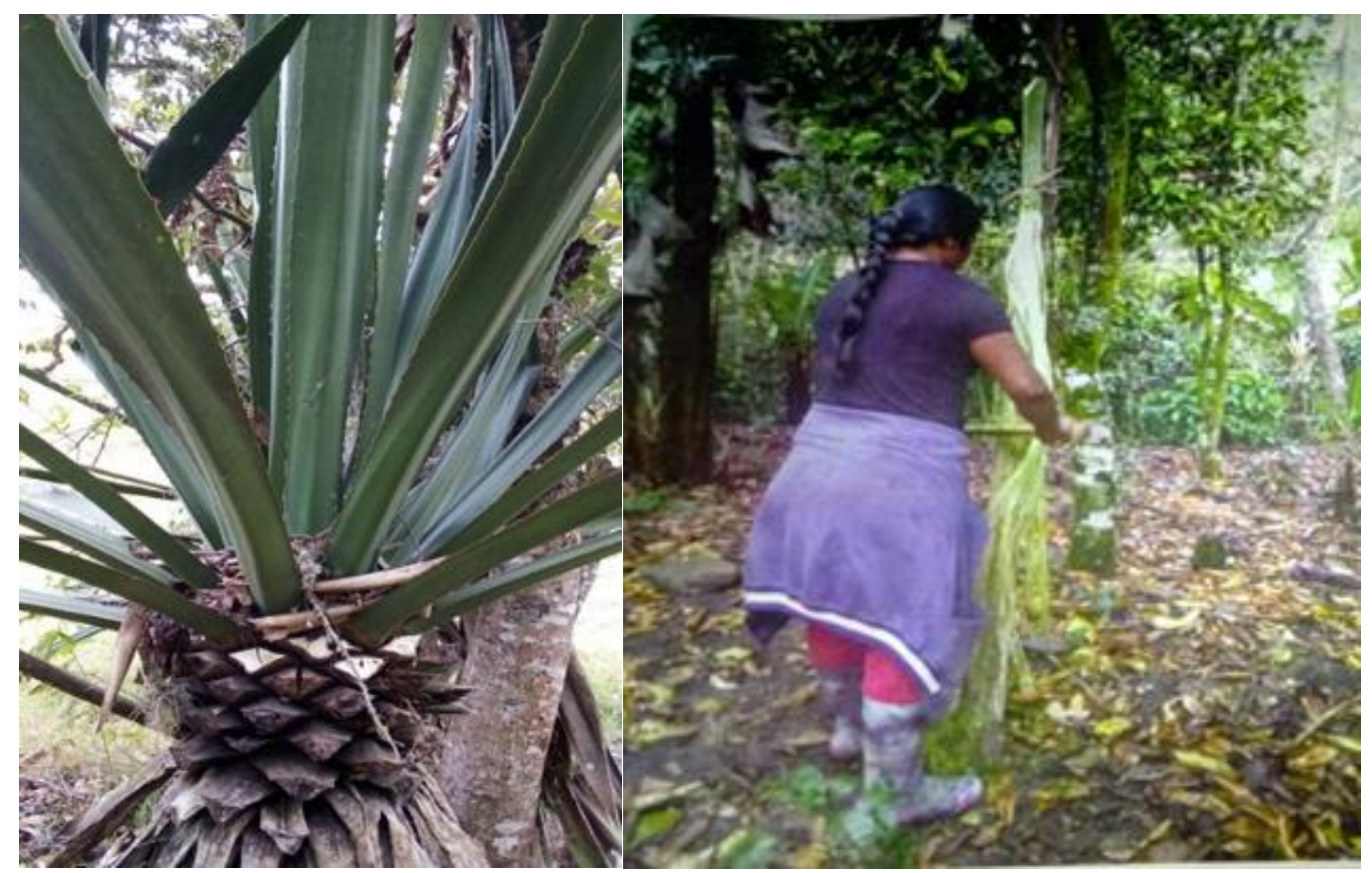

FIGURE 7. Cabuya plant. Photo: Ofelia Escué Pavi.

The connection with local nature is not only visible in the materials used, but also in the designs, shapes and inner meanings of the craft objects. Coicue says that the jigra made from cabuya is a bag that is knitted from an early age where the natural cabuya fibers are used. The jigra or "yaja" in the Nasa Yuwe language, symbolizes the belly of the woman and the Nasa way of thinking. Nasa craft makes use of simple tools which are produced replicating ancestral techniques, using materials that are locally available. (Figure $8,9,10$ ). According to the interviewed Nasa artisans, the knitting practice is not exclusive as it is accompanied by other chores on the land or in the home.

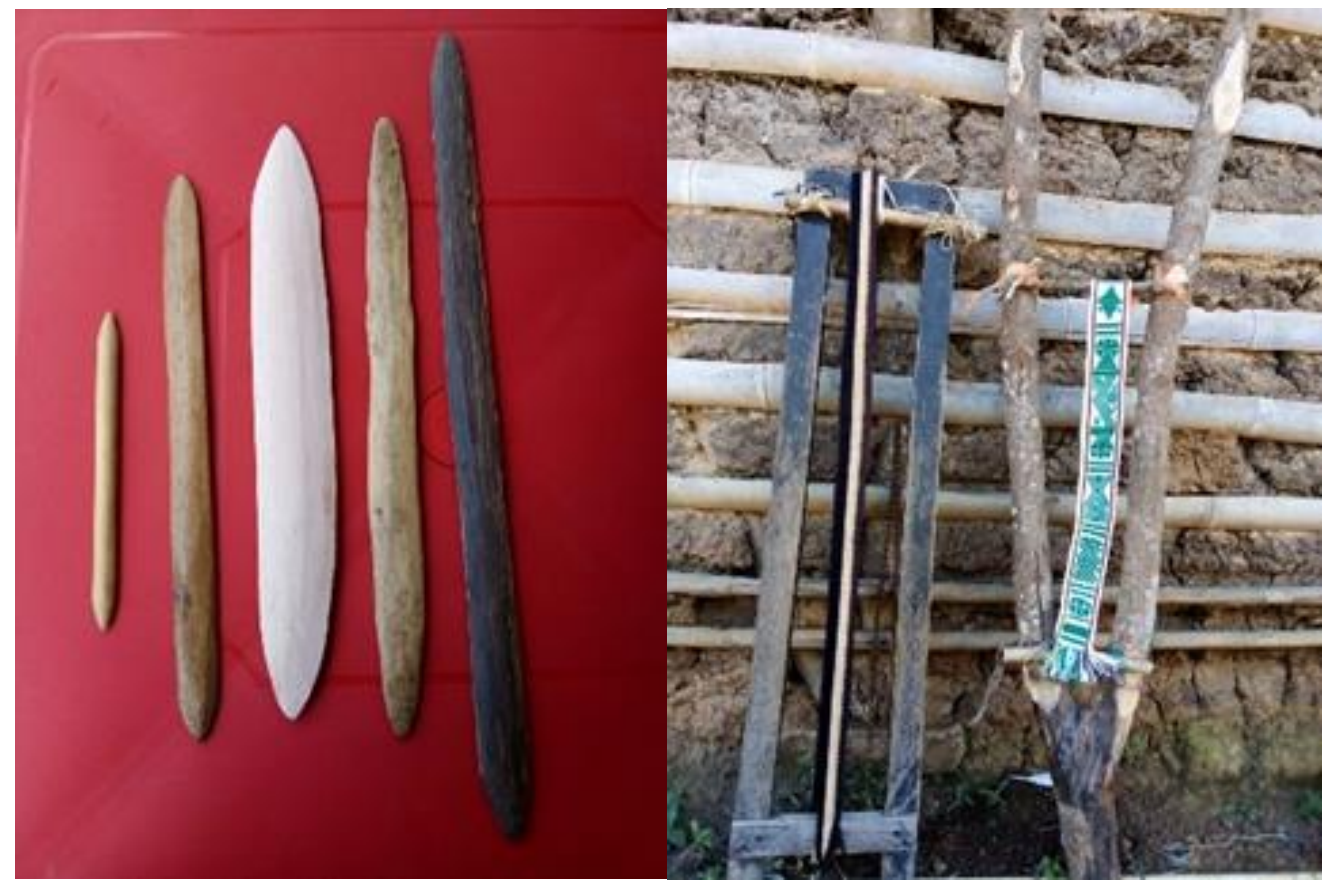

FIGURE 8 AND 9. Macanas de palo, wood sticks and telar ancestral de la orquesta. Ancestral loom of the orchestra. Photo: Ofelia Escué Pavi. 


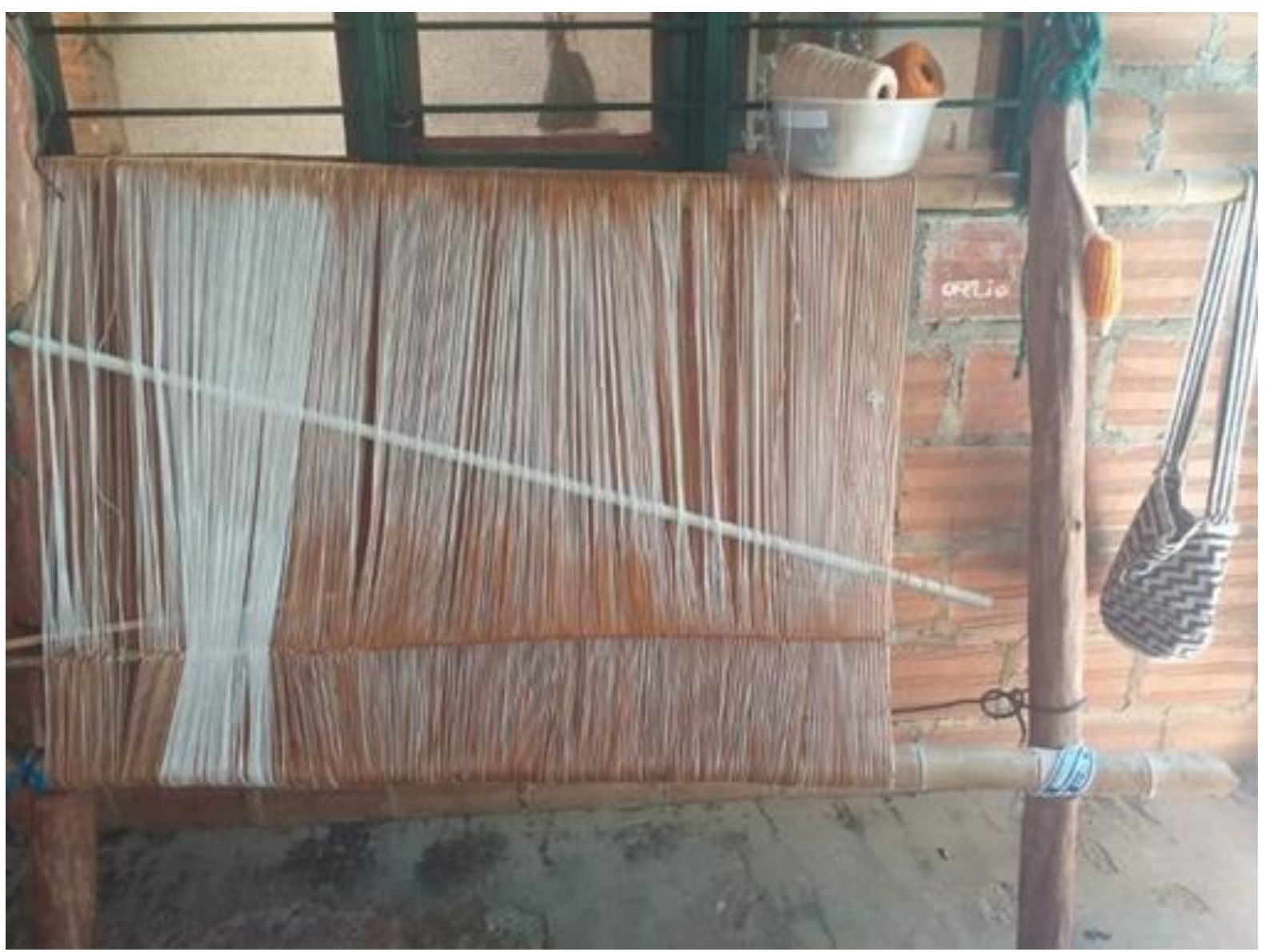

FIGURE 10. Traditional loom where ruanas, capisayo and blankets are made. Photo: John Rocha.

\section{Cultural resistance and the permanence of the worldview and its symbolism}

For the interviewees, craft has served as a mechanism of reproduction and upkeep of the indigenous world view and its particularities. For example, for the Sami artisans, the objects and their symbolism reflect the cultural heritage and identity-specific imaginaries.

Britta Marakatt-Labba uses images to show and teach Sami culture and history to the new generations. She considers that her work has a political and cultural function and she uses animals to create personalities in her embroidered pictures as well as metaphoric elements from the Sami narrative to create new sceneries with present-time meanings.

In his art, the south Sami artist Tomas Colbengtson recurs to Sami history and some of the elements of its material culture. The use of the red color together with other traditional colors is characteristic of his art which is a contemporary expression of the history of racism and systematic violence against his people, especially in the south Sami region.

For Doris Risfjell, it is important that the Sami as a collective and culture survive and continue to apply its traditions. Her husband, the south Sami artisan Sven Åke Risfjell, combines traditional Duodji objects with modern ones. "I produce objects that have a function such as knifes, blankets, cups, drums, trays and fishing sticks. Everything is made from the reindeer and I use traditional Sami patterns when adorning". (Figure 11, 12). 


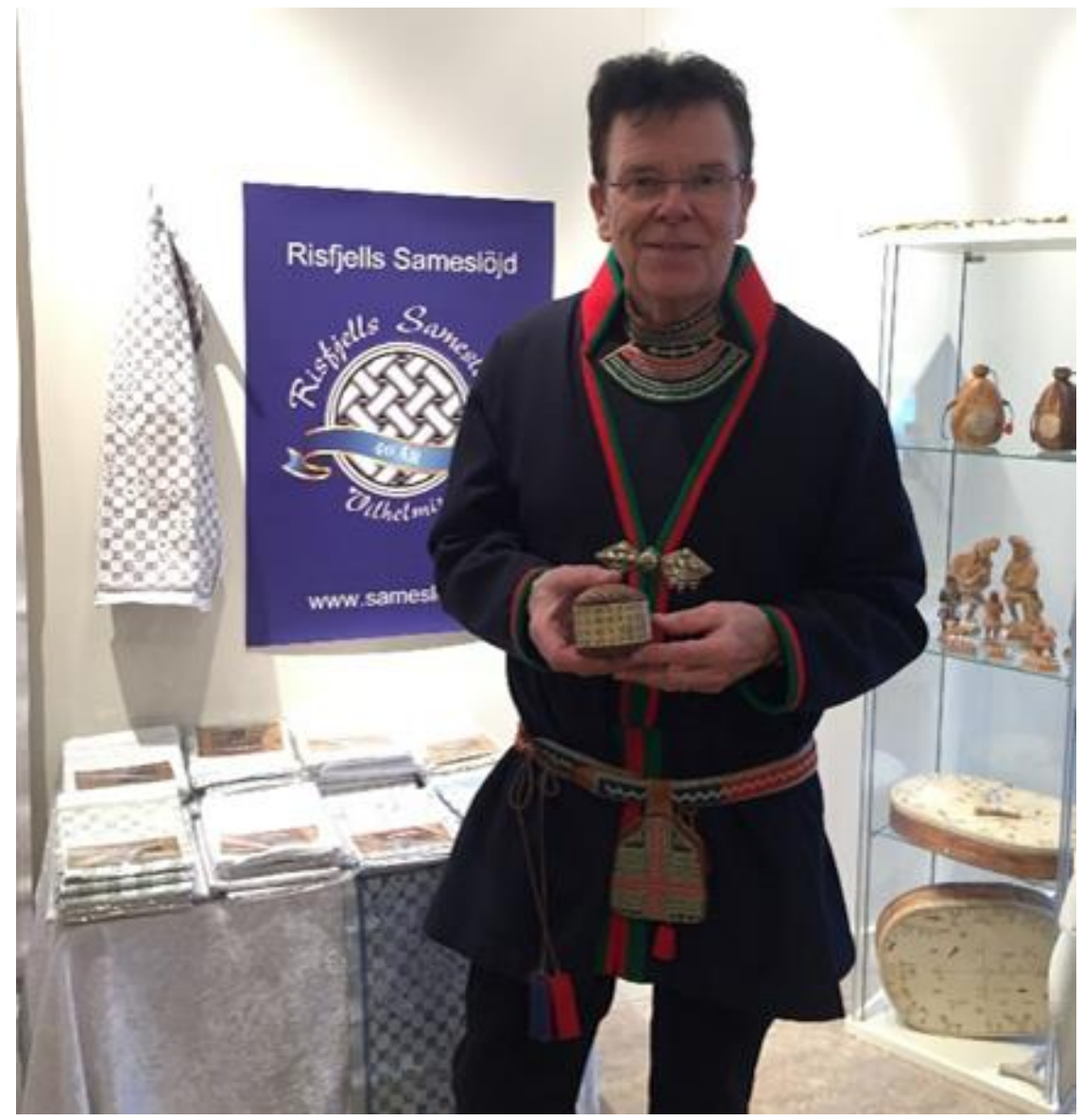

FIGURE 11. Artisan Sven Åke Risfjell and his Duodji and modern design objects. Photos: Stefanía Castelblanco

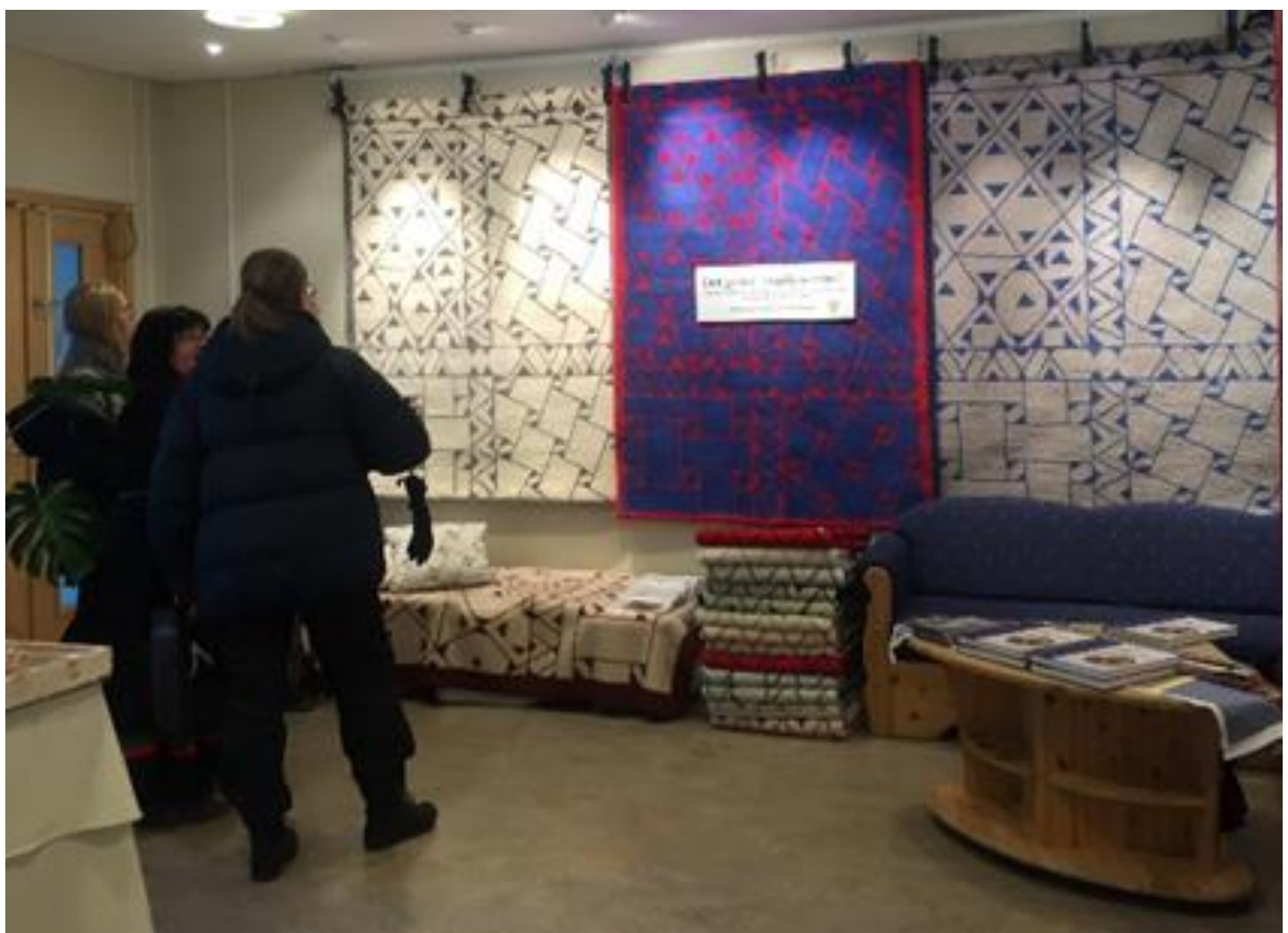

FIGURE 12. Carpets designed by Sven Åke Risfjell with south Sami patterns. Photos: Stefanía Castelblanco 
According to Seynari, the patterns that have survived the passing of time are the graphic elements in contemporary Iku knitting. Seynari tells the story of the Naboba, the first Iku woman that existed before the light. She left knitted mochilas for her descendants to replicate. These traditions are reproduced through craft and help to preserve their culture and world view. Natural elements are expressed and represented in the knitting: the rattle snake, mountains, lakes, trees, the earth, the toad, birds, etc. (figure 13)

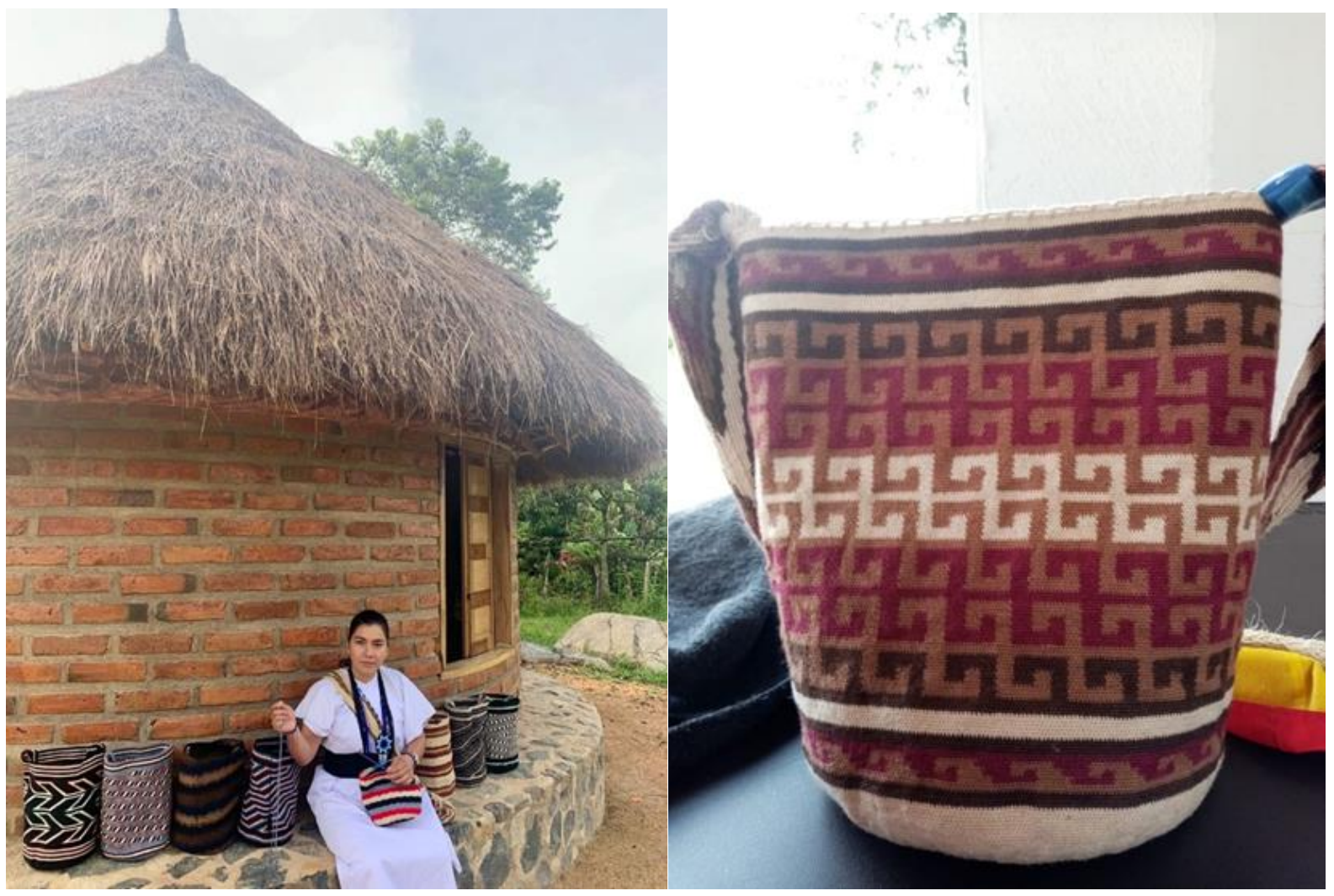

FIGURE 13. Artisan and Leader Iku Seynari Torres together with mochilas Iku. Photos: Seynari Torres

In the artisanal practice of the Nasa people, the knitting of chumbes, cuetanderas and other objects reproduces an iconography that contains graphic images of spirits, animals and other elements that narrate the spiritual history of the Nasa people (figure 14) 


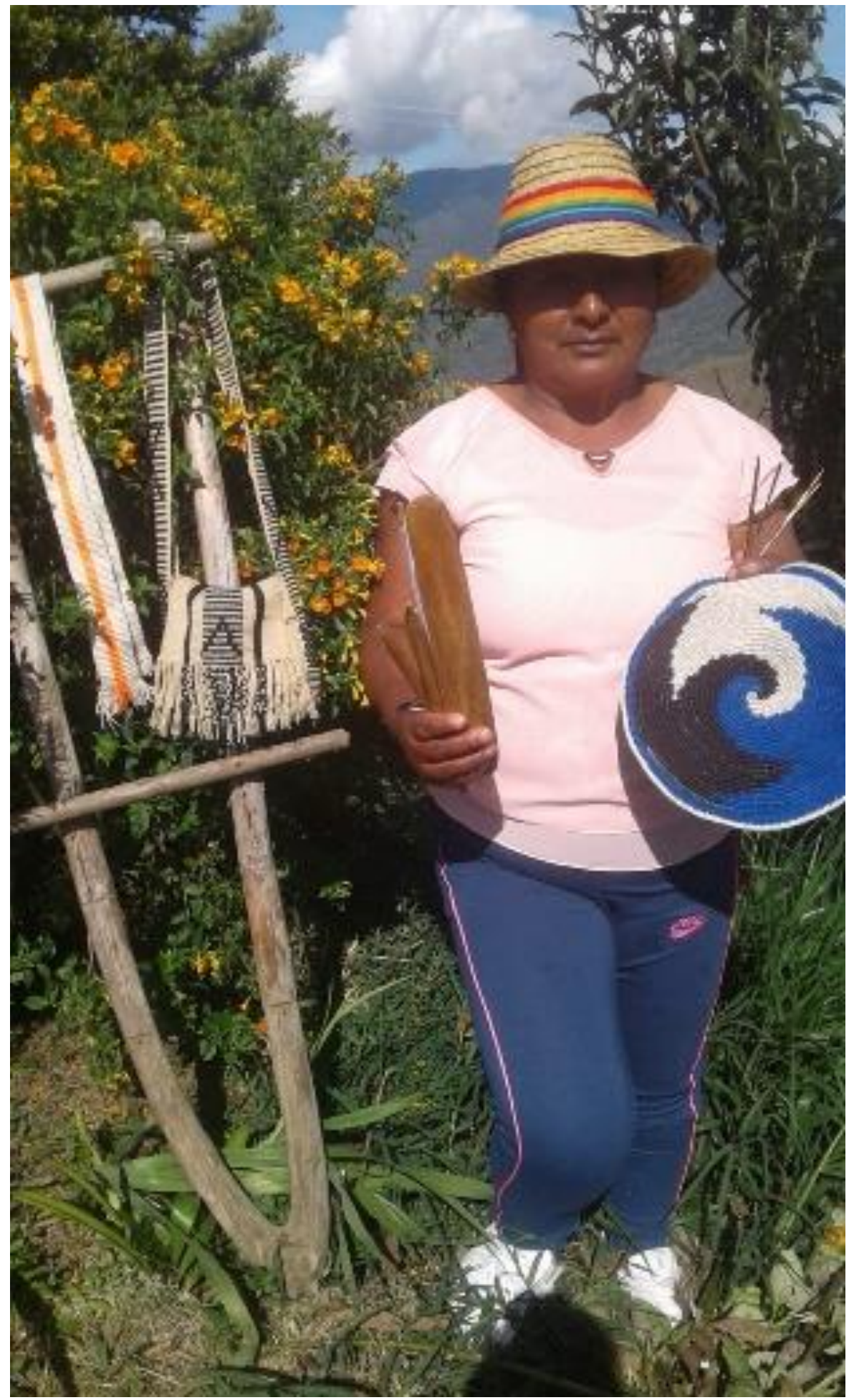

FIGURE 14. Artisan Fabiola Coicué. In Resguardo de San Francisco. Cauca-Colombia.

According to Rocha (figure 15), the spider is among the most used images in the Nasa knitting craft as it was the spider that gave the knowledge of knitting to the Nasas so that they could produce jigras and chumbes. The "cuetandera" (Figure 16) is maybe the object that best represents the Nasa people as it contains spiritual and collective meanings symbolized through the colors of the rainbow and the triangles that represent mountains and the unity and strength of the people. 


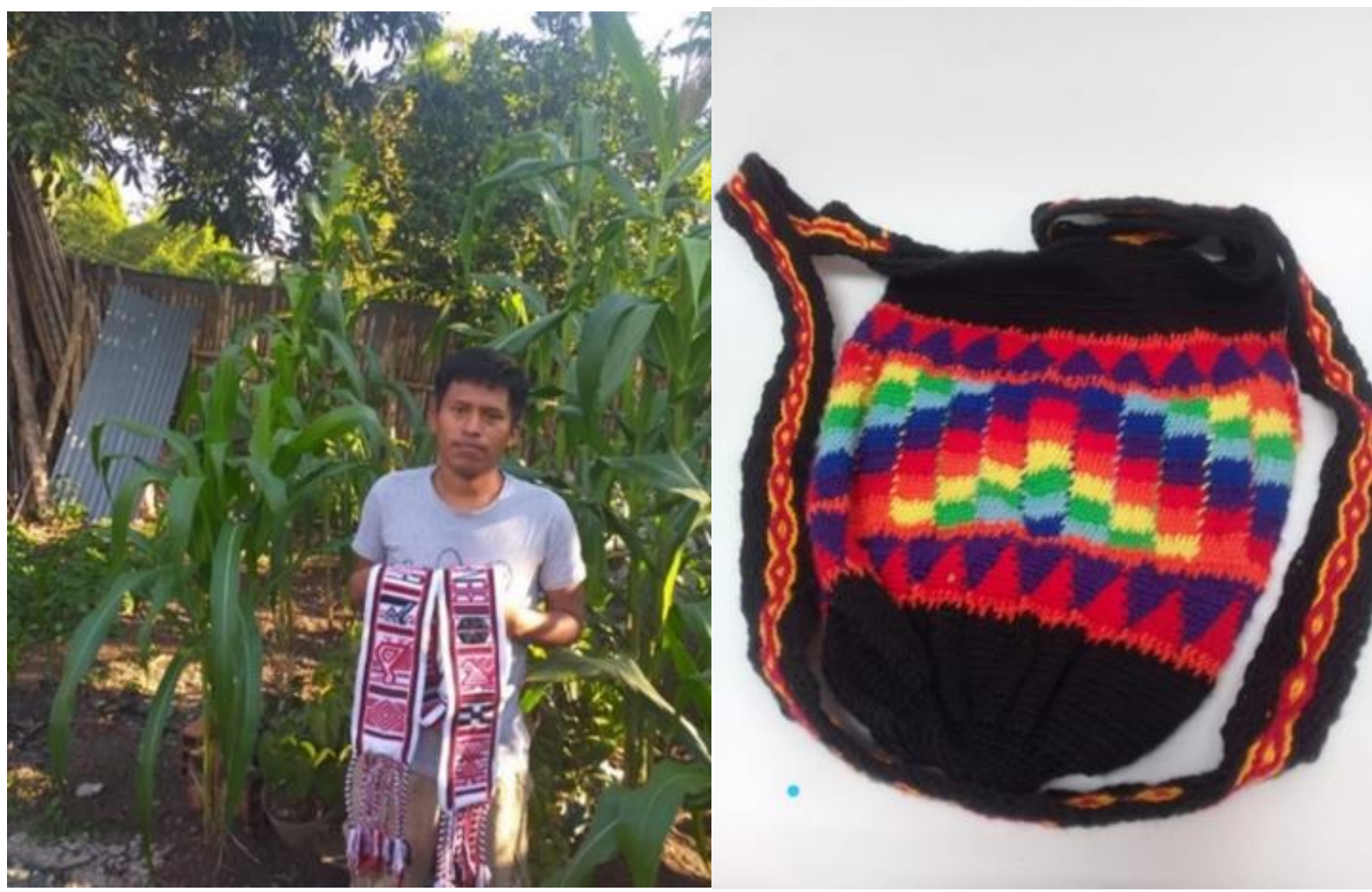

FIGURE 15 AND 16. Artisan John Rocha holding a chumbe in Resguardo de Tóez, Cauca-Colombia. Cuetandera bag made by the artisan John Rocha. Photo: John Rocha

In the Iku and Nasa cultures, the older adults are the persons that conserve the knowledge and use these objects for protection and safeguard. According to Seynari, the white Iku mochila has a sacred connotation and is used by the "Mamos" or spiritual leaders of this people. There are also special mochilas for safeguarding and protection. Escué explains that the Nasa Jigra is used as a ceremonial object by the "Thê' Wala" (spiritual authorities) during "harmonization ceremonies" where the energies of the body, the community and the territory are balanced (Quilcué, K. 2017).

\section{Craft: new meanings and functions. Adaptive resistance}

Craft practice is not a static activity but on the contrary flexible and useful in a contemporary context. In the different cultures, craft has acquired economic purpose and has served as means of dignifying subsistence. Many of the artisans encounter a way of survival through their craft practice at the same time as they feel proudness of how their culture is reproduced through this practice.

For Gunvor Guttorm, experimentation is a key aspect in the duodji craft practice. Experimenting with materials and functionality means maintaining alive learned traditions in this society as well as it gives the possibility to personal expressions. In the Sami craft practice the production processes can maintain traditional forms and at the same time incorporate modern elements such as the use of machines and tools for processing of the leather, fibers or new materials.

Doris Risfjell explains that her craft objects have contemporary applications although they are inspired by traditions. "I produce traditional items, but we are also aware of the fact that the new times may require new items, so I can also produce bags and pouches for cellular phones or iPads (...) with my husband we produce textiles with antique patterns that (he) discovered some 15 years ago".

Colbengtson places the start of his artistic activity in the first school for Sami children Skytteanska - founded in 1632 and situated in Tärna. His professor, Sunne Enoksson, taught him "hard" Duodji knowledge, which refers itself to masculine craft. At present times, Colbengtson explores images, colors and shapes based on Sami culture and the Nordic landscape, experimenting with modern tools and techniques. He has developed a new way of printing serigraphy on overlapping glass and porcelain 
and worked with serigraphy on metal (aluminum, silver and zinc) and with digital printing techniques, drawing inspiration from traditional engraving techniques (Figure 17 and 18). He is presently one of the more renowned Sami artists and his work is exhibited all over the world. For him, his objects serve the purpose of documentation: "it is very interesting to work with photography as it is a documentation of sorts. We now forget very fast (...) 10 years are really difficult to remember and two generations are very easily lost".
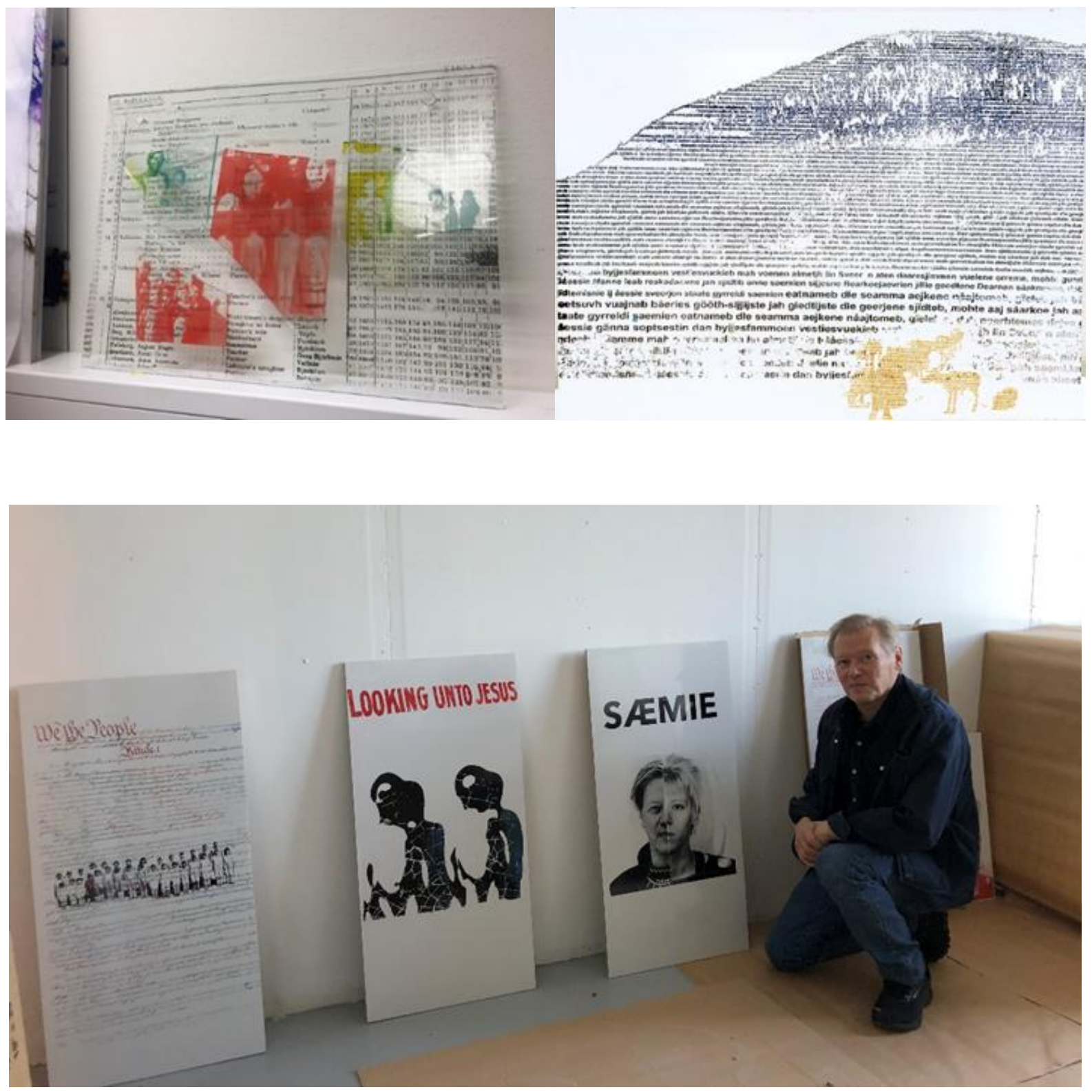

FIGURE 17 AND 18. Tomas Colbengtson, glass and porcelain artwork Photo: Stefanía Castelblanco.

\section{FINAL REFLECTION}

The Iku, Nasa and Sami craft maintain a close relation to the natural surroundings in which it is conceived and nature has served as a source of inspiration and has provided the majority of the materials, fibers and dyes used in the craft objects and tools. A harmonious relation with "mother earth" and sustainable actions are the base for craft processes among all three peoples. The knowledge of craft implies a unique awareness of the territory and its uses. Although the contact with other cultures has introduced new materials into the production processes, all three peoples seem to prefer using locally sourced 
traditional materials that decompose without leaving any trails. This is, for example, the case of the birch bark, the maguey and the cabuya. The artisanal objects act as narrative media for the communication with the surroundings and the technical and cultural conditions in which they were produced (Jurado 2002).

The world view and symbolism persist in all the studied craft processes. Craft as an object and as a creative process is the vehicle of reproduction of beliefs, ecological values, and spiritual meanings as seen most clearly in the case of the Nasa jigra and Iku mochila.

The craft seems to have acquired new meanings and is situated just between tradition and modernity. In the case of the Iku mochila, the contact with other cultures has imprinted new meanings in market logic. The mochila is seen as a commodity at the same time as it is considered an object on which ancestral knowledge is projected. Craft has functions of economic resistance and has served as source of income for artisans of the three different peoples. The craft objects have acquired new functions adjusted to modern needs; they serve for carrying iPads, cellphones computers and books at the same time as they maintain their traditional functions within agriculture and the artisan's homes. The capacity for adaptation to new contexts is one of the principal reasons for its survival. At the same time, they are used for healing, protection and generate and proudness for the artisans.

The different peoples perceive different threats against their craft. Among the Iku, the threats against their territory and intellectual property as well as gender based violence seems to be a direct threat against craft practices. For the Nasa, the jigra learning centers give a certain relief as means of conservation for this ancestral knowledge. For them, the conservation of their culture depends on the conservation of their language and craft practices. In the case of Duodji the situation seems to be more reassuring as craft is well preserved and amply recognized.

The notion of "swadeshi" is identifiable in the studied craft processes. The craft serves purposes of economic, cultural, social and political resistance and it vindicates local making processes without incurring in violent methods. Although there does not seem to be any explicit political struggle in conjunction with these craft processes, it is possible to affirm that the type of struggle proposed in Gandhi's "Satyagraha" - based on social and economic conscience, non-violence, "Ahimsa" and "do no harm", is present in these craft processes. The craft reclaims a different way of seeing and living in the world - resisting peacefully the passing of time, majority culture, violence, colonization and globalized homogenous tendencies.

Three different peoples localized in very distant contexts seem to share a peaceful resistance against threats that stem from the majority culture and ever changing contexts through their craft practices. This is an ecological, political and cultural resistance connected with sustainability and local environment and a cultural resistance in which their world view and traditional symbolism persists at the same time as new meanings and functions are adapted. Indigenous craft has much to offer for the study of the design of objects as an expression of resistance. This paper is only a small sample. their stories of resistance through craft for this academic work. Thank you for being an inspiration for other creators who, like me, seek a space to recreate our own ways of seeing and interpreting the world while existing and resisting the complex challenges that the current world entails with dignity. A special thanks to my friend and wonderful artists Tomas Colbengtson for his invaluable support and for inviting me into the Sami art, craft and design world. I would also like to offer my special thanks to Professor Gunvor Guttorm who granted me her treasured time during the Jokkmokk market and invited me to the rich discussions surrounding the market and Sami duodji. I would like to 
express my gratitude to Professor Anders Ljungberg at Konstfack University of Arts, Crafts and Design for sharing his Sami academic network and his insights during the research lab craft course. I would also like to extend my thanks to Iku indigenous leader, pacifist and environmentalist Ati Quigua for her contributions, testimony and teachings regarding the Iku culture and knitting traditions. I wish to acknowledge the help provided by La Fundación Codespa for establishing communication with the Association of artisan masters of the NASA indigenous community of northern Cauca - "Enredarte con Identidad". Finally, I wish to thank the Universidad Nacional de Colombia, the Design department and Professor César Galán - my research project supervisor for his professional guidance and constructive suggestions on this research project. 


\section{REFERENCES}

Aroca, A. (2008). Una propuesta metodológica en etnomatemática. Revista UDCA de Actualidad y Divulgación Científica. 11, 67-76. https://doi.org/10.31910/rudca.v11.n1.2008.603

Cardoso, R. (2010). Craft versus design. In G. Adamson (Ed.), The Craft Reader (pp.321-332). Berg.

Chavaco F. Y. (2019). Construcción de Significados Culturales a partir de los Tejidos que Elaboran las Mujeres Nasa de Tierradentro como estrategia de Comunicación para la Pervivencia. Journal Ciencia e Interculturalidad. 25(2). https://doi.org/10.5377/rci.v25i2.8574

Cid Jurado, A. (2002). El estudio de los objetos y la semiótica. Cuicuilco. 9(25). https://www.redalyc.org/pdf/351/35102511.pdf

Fariello M. A. (2011). Making and naming. The lexicon of studio craft. In M. E. Buszek (Ed.). Extra ordinary craft and contemporary art (pp. 25-42). Duke University Press. https://doi.org/10.2307/j.ctv11cw76n.6

Harrod, T. (2018). Craft. Documents of Contemporary art. The MIT Press/Whitechapel Gallery.

Kraus, K. (2014, April 16). The Indigenous fight against colonial veganism. https://rabble.ca/blogs/bloggers/vegan-challenge/2014/04/indigenous-fight-against-colonialveganism?fbclid=IwAR3UxVVAeYooXDEvIMrbzfDA3IQarer474CO-kf-5u-40yeHvxI2TMIdaak

López Martínez, M. (2012). Gandhi, política y satyagraha. Ra Ximhai, 8(2),39-70. https://doi.org/10.35197/rx.08.01.e.2012.02.ml

López- Martínez, M. (2013). Política sin matar. Revista Vectores de Investigación. 7, 33-84.

Mazanti, L. (2011). Super-objects: Craft as an aesthetic position. In M. E. Buszek (Ed.) Extra ordinary craft and contemporary art (pp.59-82). Duke University Press.

Organización Nacional Indígena de Colombia. (2020, May 27) Pueblos indígenas de Colombia. https://www.onic.org.co/pueblos

Quilcué, K. (2017). UMNA ÇXHAÇX ÇXHA ÇXH FXI'ZENXI Tejiendo resistencia. [Bachelor dissertation, Universidad Externado de Colombia]. UE Campus Repository. https://bdigital.uexternado.edu.co/handle/001/329

Vargas Reyes, B. \& Ariza Santamaría, R. (2019). Liberación de la madre tierra: entre la legitimidad y los usos sociales de la ilegalidad. Revista Socio-Jurídicos, 22(1), 203-231. http://dx.doi.org/10.12804/revistas.urosario.edu. co/sociojuridicos/a.7641

\footnotetext{
${ }^{1}$ In linguistics, semiotics is the science that studies systems of signs within a society.

${ }^{2}$ The object as part of a system, Jurado 2002, 3.

${ }^{3}$ López Martínez, M. makes synthesis and explanation of Gandhian political and ethical theory in his article Gandhi, política y satyagraha. RaXimhai, (2012) 8 (2) 39-70

${ }^{4}$ This terminology is based on the description made by the Iku activist Ati Quigua in an interview on the 2nd of July 2020.

${ }^{5}$ Armando Aroca identifies 16 traditional patterns reffering to the local ecosystems.

${ }^{6}$ Fique is a natural fiber made from the leaves of the Maguey plant.

${ }^{7}$ The chume or Ta'w in the Nasa language is a textile piece that contains a large portion of the Nasa iconography. According to the artisan John Rocha, the chumbe is also known as the "book of the Nasas".
} 